\title{
Impacts of climate and municipal water demand changes on ecological flows in the Columbia river basin, USA
}

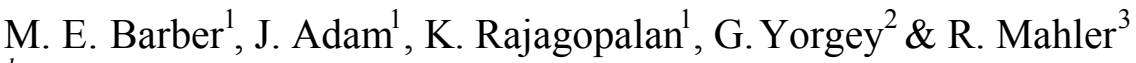 \\ ${ }^{I}$ Department of Civil and Environmental Engineering, \\ Washington State University, USA \\ ${ }^{2}$ Center for Sustaining Agriculture and Natural Resources, \\ Washington State University, USA \\ ${ }^{3}$ Soil Science and Water Quality, University of Idaho, USA
}

\begin{abstract}
Water rights in the western United States are granted under the prior appropriation doctrine; essentially first in time, first in right. Because many rights were issued prior to instream or ecological flow requirements, regulatory agencies have little authority to curtail diversions even when critical endangered species habitat is threatened. Compounding the issues is that municipal water rights throughout the Columbia River Basin were issued with significant "inchoate" portions (unused) that threaten sustainable water management as climate change and population growths alter instream flows. In many regions, this is placing challenging restrictions on management for endangered species such as salmon and bull trout species. This is slowly evolving into policies such as the one adopted by the state of Washington where state investment in water projects reserves at least $1 / 3$ for instream uses.

We developed a combined VIC/CropSyst model that predicted water supply changes in the Columbia River watershed ( 7 states and a portion of British Columbia) due to climate change in the 2030's and, by examining municipal water plans and population growth models, predicted future water demands within existing water rights and evaluated impacts to instream flows. There is an expected $26 \%$ increase in municipal demand ( $700 \mathrm{MCM})$ in the State of Washington alone with just over $50 \%$ being consumptively used. Other upstream communities in Idaho, Montana, and Oregon face similar situations to varying degrees. Results indicated that communities located on several tributaries will
\end{abstract}


face substantial challenges in terms of sustainable development if improvements in infrastructure, conservation, and technology are not rapidly deployed.

Keywords: instream flow requirements, endangered species, climate change, prior appropriation doctrine.

\section{Introduction}

Accurate estimates of streamflows within the Columbia River Basin are important for numerous planning and management decisions related to demand sectors such as power generation, agricultural use, municipal supply, and endangered species flows. Whereas current flows are reasonably well known, there exists a greater degree of uncertainty regarding future supplies of water resources within the basin. Since water drives economic development and cultural identity in the Pacific Northwest, it is regionally important that future water availability, as well as the demand for this resource, be determined. Although seasonal differences in temperature and amounts of precipitation within the basin make this an inexact science, what can be determined are programmatic releases from dams and impoundments (minimum - maximum) during normal operating conditions and instream flow requirements legislated through water rights agreements, Endangered Species Act (ESA) requirements, adjudicated settlements, or other agreements entered into on a state to state or international (Canada, United States) basis.

The 260,000 square mile watershed encompasses significant portions of four U.S. states and British Columbia as well as smaller portions of three other states (USEPA [1]). Muckleston [2] reported that the CRB catchment area drains 95\% of Idaho, $69 \%$ of Washington, $57 \%$ of Oregon, $17 \%$ of Montana, and $9 \%$ of British Columbia (BC) as well as relatively small percentages of Wyoming, Nevada, and Utah. Minimum instream flows from these upstream source areas have the potential to impact available water supplies in Washington by affecting inflows into the state and by setting limits on withdrawals and reservoir operations within the State. This section of the report explains the methodology used to examine minimum instream flow requirements within the watershed.

There are currently two important unresolved concerns surrounding the legislated/mandated minimum instream flows on streams entering Washington and the available supply of water within the State. The first involves the overall state of water rights in the Pacific Northwest and their ongoing adjudication (including Tribal claims). The second involves past and ongoing biological opinions (BiOp) relating to the ESA and their interpretation with respect to reservoir releases and hydropower operations. These two topics may impact the results of this study in the future. For the present, however, the current conditions were assumed to apply in the future. Furthermore, it is important to point out that most instream flows are junior to existing water rights so to the extent that these water rights are not currently taking their full allotments, the instream flow requirements do not guarantee that streamflows won't fall below that target. 


\section{Background}

Water rights in the western United States are granted by each state under the prior appropriation doctrine; first in time, first in right [3]. Because many rights were issued prior to instream or ecological flow requirements, regulatory agencies have little authority to curtail diversions even when critical endangered species habitat is threatened. Compounding the issues is that municipal water rights throughout the Columbia River Basin were issued with significant "inchoate" portions (unused) that threaten sustainable water management as climate change and population growths alter instream flows. In many regions, this is placing challenging restrictions on management for endangered species such as salmon and other aquatic species.

The Spokane River, for example, has seen low flows decline from over $2,000 \mathrm{ft}^{3} / \mathrm{s}$ to $500 \mathrm{ft}^{3} / \mathrm{s}$ (see Figure 1) over the past 112 years and is well below the $850 \mathrm{ft}^{3} / \mathrm{s}$ minimum summer instream flow currently recommended by the Washington Department of Fish and Wildlife (Beecher [4]).

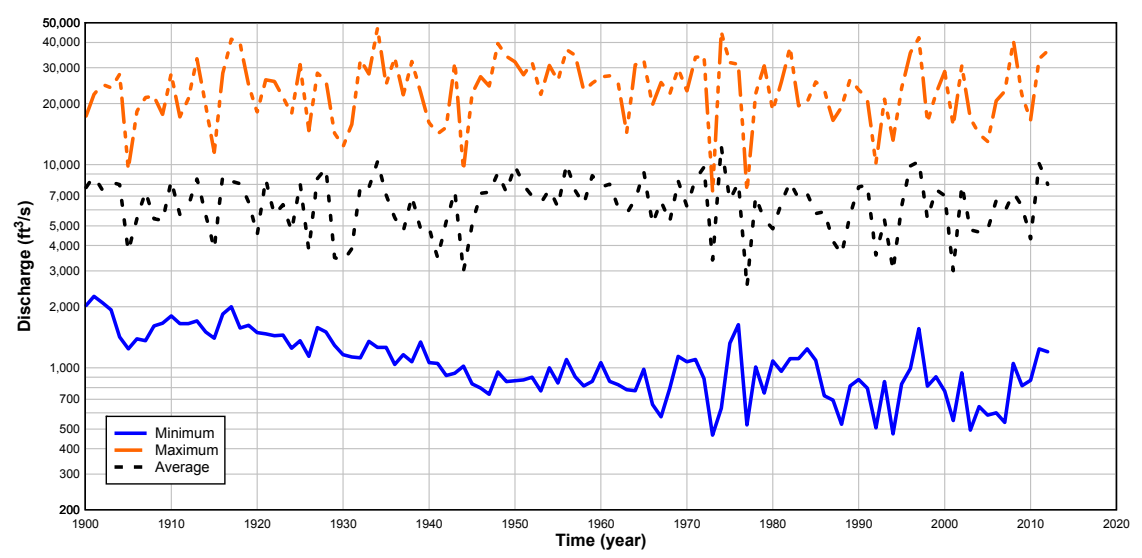

Figure 1: Long-term streamflow for Spokane, Washington (Barber et al. [5]).

According to the Washington Department of Ecology (2003), if 90\% of the inchoate rights were used, river flows in the mid to late summer would decrease by approximately $250 \mathrm{ft}^{3} / \mathrm{s}$. When faced with uncertainties in water supply due to climate change and population growth, it is evident that estimates are needed for future water demands for municipal diversions.

\section{Methodology}

The waters of the Columbia River Basin support a variety of fish and other wildlife important to maintaining cultural, environmental, and recreational opportunities, including several ESA-listed threatened and endangered fish 
stocks. Wildlife and fish (including both listed and non-listed species) help support a vibrant tourism, recreation, and fishing industry in the Columbia River Basin, one that plays a vital role in maintaining the rural economy. While values specifically derived for eastern WA were not available, recreational spending associated with fishing, hunting, and wildlife viewing was estimated to be $\$ 3.1$ billion statewide in 2006, according to a study by the US Department of Fish and Wildlife [6].

Using state of the art modeling techniques and economic scenarios, a water supply and demand model were constructed for the entire watershed (Barber et al. [7]). Model results were used to evaluate the impacts of climate change, regional and global economic conditions and state level water management actions on surface water supplies and irrigation demands across the Columbia River Basin. The Forecast evaluated surface water supply and demand at three geographic tiers: the entire Columbia River Basin, Eastern Washington's watersheds and Washington's Columbia River mainstem (see Figure 2). The project used 30 years of historical data (1977-2006) and projected these conditions forward to 2030s. On the demand side, irrigation demands were forecast for roughly 40 primary Washington crop types over a broad range of alternative scenarios including climate change, economic scenarios, increased water capacity through development of water supply projects, and various cost recovery rates for water supply development. Municipal demand forecasting (including self-supplied domestic use) was forecasted in the Washington portion of the basin using data from county level population estimates from the Office of Financial Management, combined with data in water treatment plant and water system plans submitted to the Washington State Department of Health. For those municipalities where data allowed, industrial growth was also included.

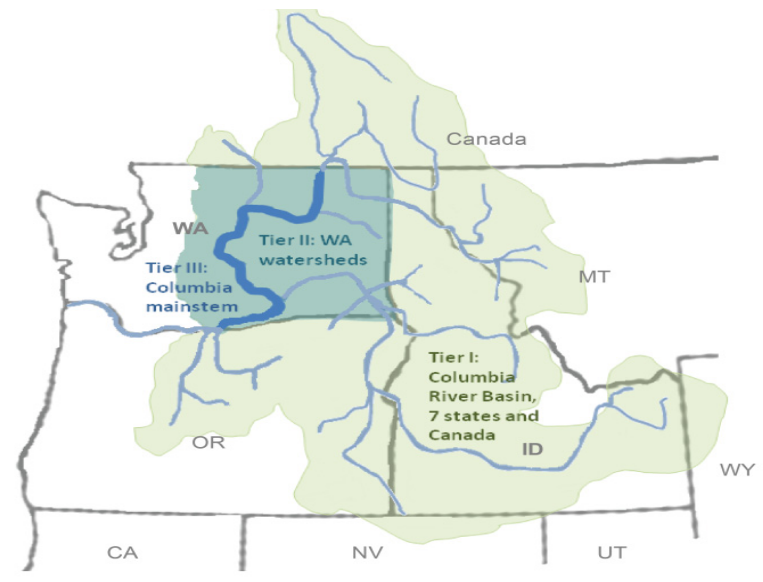

Figure 2: Modeling domains for water supply and demand was forecast (Yorgey et al. [8]). 
Municipal supply data was obtained from water system plans submitted to the Washington State Department of Health. The plans were obtained for 1-3 municipalities within each WRIA and included both domestic and industrial water supplied by the municipality. One challenge was that the water system plans were developed across a variety of years so consistent years of analysis were developed. A consistent year of 2000 was used to provide a common base so populations and supplies were scaled and entered into a spreadsheet.

County level population estimates for eastern Washington in 2030 were obtained from the Office of Financial Management (www.ofm.wa.gov/pop/gma). These were converted to WRIA level estimates using several steps. First, by subtracting major urban area population from the total population and dividing by the county area, average rural densities for each county could be determined. Overlaying and summing the appropriate WRIA areas on top of the contributing county areas in GIS allowed "rural" WRIA populations to be determined. Urban populations were added according to their geographic location so total population could be determined.

These figures were used to compute an Average Daily Demand (ADD) in terms of gallons per capita per day (gpcd). In some instances, diversions were much higher because of system leaks. Total WRIA demand is based on the assumption that all people in the WRIA will use the average demand of from the nearby municipalities. Overall, WRIA demands varied considerably throughout eastern Washington following a trend reported by a 2005 USGS study of domestic use (Lane [9]). The average total domestic and industrial demand (including system losses) was approximately $277 \mathrm{gpcd}$. This compares very well to the 285 gpcd for eastern Washington estimated by Lane [9].

Consumptive use was estimated by examining the difference between water diversions and discharges at corresponding wastewater treatment plants (WWTP). This approach has been used by others while recognizing the potential for discrepancies due to municipal inflow and infiltration (I\&I). Loss or addition of flow due to groundwater exchanges in aging wastewater collection systems can be significant.

Hughes [10] conducted a study of 52 municipal systems in Utah where winter water diversions were compared to wastewater discharges. Since winter diversions are assumed to be primarily for indoor uses, a perfect ratio of 1.0 would reflect $100 \%$ agreement between supply and wastewater return. The Utah Division of Water Resources has traditionally estimated this fraction to be approximately 0.90 (Oregon uses 0.80-0.90 (Cooper [11]). However, the study by Hughes found 17 ratios were greater than 1.0 and 16 ratios were less than 0.70 . Consequently, $63 \%$ of the systems likely suffered either from excess infiltration into the system $(>1.0)$ or exfiltration out $(<0.7)$. Excluding the values outside the 0.7-1.0 range, the remaining systems averaged a supply/effluent ration of 0.83 during the winter. Similar analysis of summer flows revealed a return flow ratio of 0.51 indicating nearly half the flow is used for outside irrigation.

In our analysis, 28 of 34 WRIA produced values where WWTP discharges were less than diverted amounts thus producing positive consumptive use values. 
The average of the 28 positive values was substituted for the six negative values. Using this methodology, an additional consumptive use amount of 60,000 acrefeet/year (5,000 AF/month) will be required by eastern Washington WRIAs by 2030. This represents approximately $55 \%$ of the additional consumptive use quantity which may be high compared to other investigations. Nevertheless, as an initial estimate totaling $84 \mathrm{ft}^{3} / \mathrm{s}$ at the mouth of the Columbia River, the values were used to predict future consumptive municipal and industrial water demands. No attempt was made to distribute these amounts throughout the year. Future analysis should examine monthly variations instead of simply dividing the annual total by 12 .

Census estimates show population growth in neighboring states such as Idaho, Oregon, and Montana also growing over the next 20 years. US Census statistics project total population to grow by $25.6,26.2$ and 5.6 percent in the three states, respectively. Without concerted conservation efforts, population growth will certainly increase demands on water flowing into Washington State. Although Idaho has not released county by county growth projections, it is safe to assume that the water will reduce inflows into Washington. A study of the Spokane River basin by the state of Idaho projected an addition consumptive demand on the river of $31 \mathrm{ft}^{3} / \mathrm{s}$ by 2060 (IDWRB [12]).

\section{Results and discussion}

Population growth in Washington will increase municipal diversions by approximately 117,000 acre-feet/year by 2030 including both consumptive and non-consumptive uses. The additional consumptive use is estimated to be 58,800 acre-feet/year (see Table 1). As illustrated below, these average annual values are highly variable among the tributary watersheds of the Columbia River basin. When superimposed on climate scenarios for the Pacific Northwest, we can see significant differences between projected supply and anticipated demands. Figure 3 illustrates the historical differences in the Yakima River watershed where summer demand already exceeds supply. Definitions of the descriptions used to quantify flows and demands are presented in Figure 4. Projected worsening deficits are shown in Figure 5 for one typical climate scenario. Direct comparison to Figure 3 illustrates additional shortages extending earlier into June that previous years and additional net water needs. Other watersheds in the basin demonstrated similar results.

The demands shown in Table 1 represent average annual demands which likely means the values shown in Figures 3 and 5 are even worse because summer diversions will likely be substantially higher than winter diversions. However, accounting for this meant that we would have to operate numerous local reservoirs which was beyond the scope of the present project. Nevertheless, the trend is reasonably clear with respect to adverse impacts. 


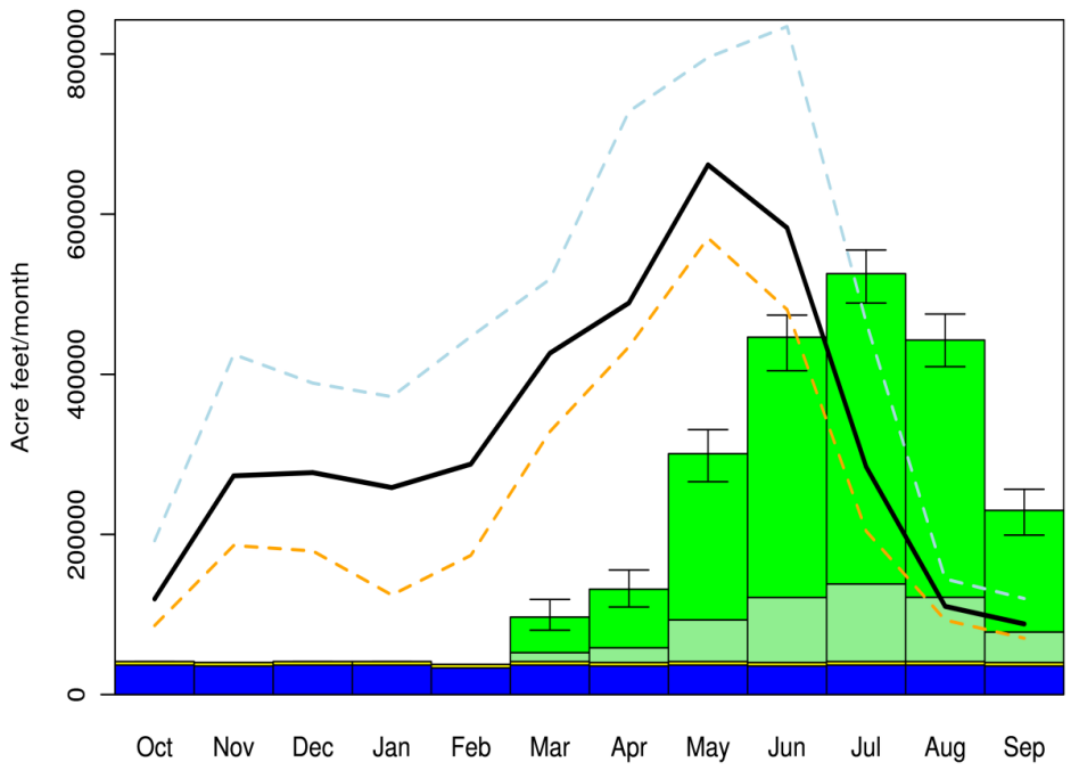

Figure 3: Yakima River basin under historical climate scenario (Adam et al. [13]).

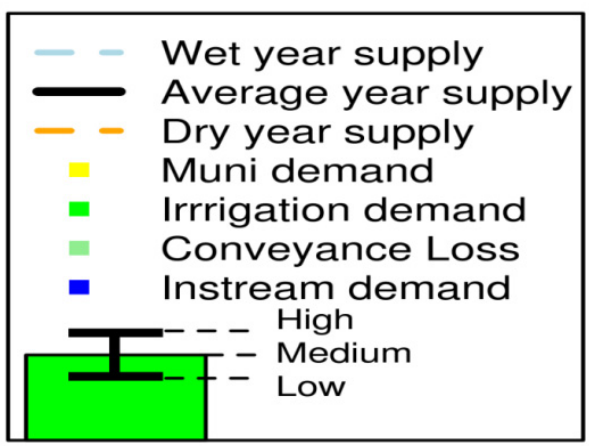

Figure 4: Definition of symbols used in Figures 3 and 5. 


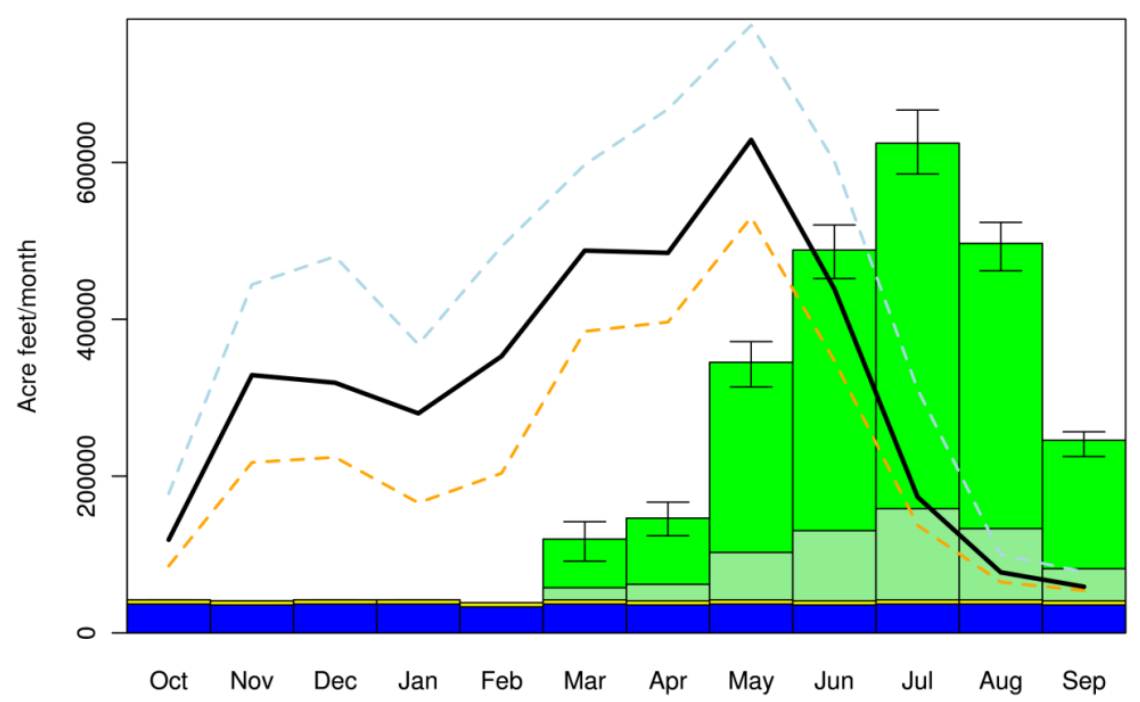

Figure 5: Yakima River basin under Hadcm_B1 climate scenario.

\section{Conclusions and recommendations}

Within the state of Washington we expect to see a 117,000 acre-feet growth in municipal diversion requirements by 2030 with approximately $55 \%$ of that amount consumptively used. When examined at the Columbia River watershed scale, this represents an average annual flow decrease of approximately $85 \mathrm{ft}^{3} / \mathrm{s}$ which is fairly inconsequential even when seasonal fluctuations are considered and upstream diversions from Idaho and Oregon are factored into the results. However, since many municipalities draw water from smaller tributaries, the combined impacts of population growth and inchoate municipal demands will likely result in continued reductions in summer low flow conditions on tributary streams unless strategies are implemented to reduce impacts. These impacts may be severe locally due to seasonal effects or because of spatial distance between diversion and waste water effluent discharge locations means that even the nonconsumptive fraction of the water may be lost to reaches of the stream. Tributaries such as the Boise, Spokane, Walla Walla, and Yakima Rivers appear to be threatened.

Estimates for additional municipal water demand were based on current water use reported in their most recent water system plans. Many of the water system plans had substantial amounts of unaccounted for water. Improvements to distribution systems could reduce diversion requirements substantially. This effort did not examine the impacts of trends, system repairs, and conservation 
Table 1: $\quad$ Municipal demand forecast.

\begin{tabular}{|c|c|c|c|c|}
\hline Watershed Name & $\begin{array}{c}2010 \\
\text { Population } \\
\text { Estimate }\end{array}$ & $\begin{array}{c}2030 \\
\text { Population } \\
\text { Estimate }\end{array}$ & $\begin{array}{l}\text { Change in } \\
\text { Diversion } \\
(\mathrm{AF} / \mathrm{YR})\end{array}$ & $\begin{array}{c}\text { Change in } \\
\text { Consumptive } \\
\text { Use } \\
\text { (AF/YR) }\end{array}$ \\
\hline Wind-White Salmon & 8,929 & 11,222 & 350 & 63 \\
\hline Klickitat & 43,239 & 54,252 & 5,552 & 1,844 \\
\hline Rock-Glade & 95,177 & 109,994 & 2,559 & 858 \\
\hline WallaWalla & 47,933 & 56,594 & 1,880 & 1,450 \\
\hline Lower Snake & 38,279 & 50,977 & 3,258 & 345 \\
\hline Palouse & 140,526 & 169,437 & 3,415 & 4,839 \\
\hline Middle Snake & 35,190 & 40,823 & 2,737 & 2,041 \\
\hline Esquatzel Coulee & 65,582 & 88,732 & 12,489 & 7,998 \\
\hline Lower Yakima & 190,944 & 228,883 & 11,342 & 5,933 \\
\hline Naches & 58,006 & 71,560 & 2,412 & 1,967 \\
\hline UpperYakima & 50,120 & 60,656 & 3,276 & 2,895 \\
\hline Alkali-Squilchuck & 38,731 & 45,193 & 2,380 & 2,082 \\
\hline Lower Crab & 61,420 & 70,067 & 3,794 & 2,534 \\
\hline Grand Coulee & 22,381 & 25,608 & 2,958 & 441 \\
\hline Upper Crab-Wilson & 24,986 & 30,949 & 3,387 & 2,655 \\
\hline Moses Coulee & 24,548 & 31,306 & 1,232 & 19 \\
\hline Wenatchee & 33,261 & 42,931 & 3,374 & 1,364 \\
\hline Entiat & 11,556 & 14,916 & 416 & 195 \\
\hline Chelan & 24,951 & 32,196 & 1,787 & 734 \\
\hline Methow & 16,476 & 19,737 & 1,141 & 360 \\
\hline Okanogan & 16,220 & 19,422 & 1,141 & 410 \\
\hline Foster & 15,623 & 20,000 & 1,396 & 804 \\
\hline Nespelem & 1,601 & 1,935 & 95 & 7 \\
\hline Sanpoil & 4,717 & 5,999 & 364 & 41 \\
\hline Lower Lake Roosevelt & 2,444 & 3,115 & 264 & 149 \\
\hline LowerSpokane & 74,111 & 95,324 & 5,432 & 1,259 \\
\hline LittleSpokane & 113,399 & 142,580 & 11,756 & 6,443 \\
\hline Hangman & 114,472 & 143,147 & 3,778 & 1,701 \\
\hline Middle Spokane & 70,314 & 88,000 & 5,888 & 2,577 \\
\hline Middle Lake Roosevelt & 8,091 & 12,292 & 1,230 & 703 \\
\hline Colville & 17,396 & 27,766 & 3,036 & 1,736 \\
\hline Kettle & 6,001 & 8,275 & 666 & 381 \\
\hline Upper Lake Roosevelt & 9,612 & 15,276 & 3,099 & 2,886 \\
\hline Pend Oreille & 11,546 & 15,712 & 1,496 & 426 \\
\hline
\end{tabular}


efforts on future demands. For instance, eliminating system losses would result in a net savings of nearly 55,000 AFY currently and 69,000 AFY by 2030. Of equal importance is the potential impact of conservation practices. Reducing current demands by $10 \%$ would reduce current diversion requirements by 45,000 AFY and projected future demand by 57,000 AFY and future consumptive use by approximately 30,000 AFY.

\section{Acknowledgements}

This work was funded by the Washington State Department of Ecology through a grant provided to the State of Washington Water Research Center. The authors wish to express their gratitude to Derik Sandison, Dan Haller, and Carolyn Comeau for their support and guidance.

\section{References}

[1] U.S. Environmental Protection Agency (USEPA). Learn About the Columbia River. Retrieved October 3, 2011, http://yosemite.epa. gov/r10/ECOCOMM.NSF/Columbia/Columbia+Learn/

[2] Muckleston, K.W. International management in Columbia River system. 2003. UNESCO/IHP/WWAP, Technical Documents in Hydrology, PC-CP series \#12.

[3] Gregoire C.O., Pharris J.K., and McDonald, PT. An introduction to Washington water law. 2000. Washington Office of Attorney General, Olympia, WA.

[4] Beecher H. 2012 Instream flow recommendations for the Spokane River. Washington Department of Fish and Wildlife, Olympia, WA.

[5] Barber M. E., Hossain A., Covert J. J. and Gregory, G. J. Augmentation of Seasonal Low Stream Flows by Artificial Recharge in the Spokane ValleyRathdrum Prairie Aquifer of Idaho and Washington. 2009. Hydrogeology Journal, 17:1459-1470.

[6] U.S. Fish and Wildlife Service and U.S. Census Bureau. National survey of fishing, hunting, and wildlife-associated recreation.2006. http:// www.census.gov/prod/www/abs/fishing.html

[7] Barber M., Adam J., Brady M., Chinnayakanahalli K., Rajagopalan K., Dinesh S., Kruger C., Stockle C., and Yorgey G. Global change implications on long-term water supply and demand forecasts in the Columbia River basin. 2012. 4th International Conference on Sustainable Irrigation and Drainage: Management, Technologies and Policies. Wessex Institute of Technology, Adelaide, Australia.

[8] Yorgey G.G., Rajagopalan K., Chinnayakanahalli K., Brady M., Barber M.E., Nelson R., Stockle C.S., Kruger C.E., Dinesh S., Malek K., Yoder J., and Adam J.C. Columbia River Basin Long-Term Water Supply and Demand Forecast. 2011, Washington State Legislative Report, http:/www.ecy.wa.gov/biblio/1112011.html 
[9] Lane R.C. Estimated water use in Washington. 2005. U.S. Geological Survey Scientific Investigations Report 2009-5128, 30 p.

[10] Hughes T.C. Consumptive use of municipal water supply. 1996. Utah Water Research Laboratory, Logan, UT. http://www.cachecounty.org/docs/ waterpolicy/docs//Consumptive\% 20Use\%20of\%20Municipal\%20Water\% 20Supply.pdf

[11] Cooper R.M. Determining surface water availability in Oregon.2002. Open File Report SW 02-002. Oregon Water Resources Department, Salem, OR.http://www.oregon.gov/OWRD/WR/docs/SW02-002.pdf?ga=t

[12] Idaho Water Resource Board (IDWRB). Rathdrum Prairie aquifer comprehensive aquifer management plan. 2011. http://www.idwr.idaho.gov /waterboard/WaterPlanning/CAMP/RP_CAMP/pdf/2011/RP_CAMP_final Adopted_Plan.pdf

[13] ÂAam J., Stockle C., Brady M., Yoder J., Marsh T., Barber M., and Kruger C. Incorporating agricultural management into an earth system model for the Pacific Northwest region. 2011. Department of Natural Resources, Washington. 